University of Nebraska - Lincoln

DigitalCommons@University of Nebraska - Lincoln

Faculty Publications from the Harold W. Manter Laboratory of Parasitology

10-1977

\title{
Two New Zoogonid Digenea from Deep Sea Fishes in the Gulf of Panama
}

Robin M. Overstreet

Gulf Coast Research Laboratory, robin.overstreet@usm.edu

Mary Lou Hanson Pritchard

University of Nebraska - Lincoln

Follow this and additional works at: https://digitalcommons.unl.edu/parasitologyfacpubs

Part of the Parasitology Commons

Overstreet, Robin M. and Pritchard, Mary Lou Hanson, "Two New Zoogonid Digenea from Deep Sea Fishes in the Gulf of Panama" (1977). Faculty Publications from the Harold W. Manter Laboratory of Parasitology. 486.

https://digitalcommons.unl.edu/parasitologyfacpubs/486

This Article is brought to you for free and open access by the Parasitology, Harold W. Manter Laboratory of at DigitalCommons@University of Nebraska - Lincoln. It has been accepted for inclusion in Faculty Publications from the Harold W. Manter Laboratory of Parasitology by an authorized administrator of DigitalCommons@University of Nebraska - Lincoln. 


\title{
TWO NEW ZOOGONID DIGENEA FROM DEEP-SEA FISHES IN THE GULF OF PANAMA
}

\author{
Robin M. Overstreet* and Mary Hanson Pritchard $\dagger$
}

ABSTRACT: Panopula cavernossa gen. et sp. $n$. from the intestine of the brotulid Enchelybrotula (?) paucidens differs from other members of the Steganodermatinae by having testes near the anterior of the acetabulum, a posttesticular ovary, and a postequatorial acetabulum. Two related species are transferred to the genus Brachyenteron as B. pycnorganum comb. $\mathrm{n}$. and B. spinosum comb. $\mathrm{n}$. Neosteganoderma gillissi sp. $\mathrm{n}$. from the synaphobranchid eel Synaphobranchus bathybius differs from $N$. glandulosum and $N$. polymixiae, the most similar species, because conspicuous glandular cells envelop the esophagus and pharynx, others about the genital atrium occur in elongated sacs, epithelium is lacking at the cecal bifurcation, and the cirrus sac is straight. We establish $N$. infundibulum comb. $\mathrm{n}$. and expand Steganodermatinae to include Brevicreadium congeri and Hudsonia agassizi.

Two new species of the Steganodermatinae Yamaguti 1934, one representing a new genus, infected two benthic fishes from water deeper than 3,000 meters in the eastern Pacific Ocean where the muddy substratum contained considerable woody debris.

All specimens were removed alive from recently trawled hosts aboard the University of Miami's R/V JAMES M. GILLISS and fixed under slight coverslip pressure with hot AFA solution. We stained them in Van Cleave's hematoxylin and mounted them in Permount. All measurements are in micrometers, and figures were drawn with the aid of a drawing tube. Hosts have been deposited in the museum of Rosenstiel School of Marine and Atmospheric Science, University of Miami.

\section{Panopula gen. n.}

Diagnosis: Body fusiform, spinose. Acetabulum large relative to body size, at or posterior to equatorial level. Prepharynx short; esophagus longer than pharynx; ceca terminating near equatorial level. Testes at or slightly anterior to acetabular level. Genital pore sinistral. Cirrus sac prominent, preacetabular, containing unspined cirrus, pars prostatica, and twisted seminal vesicle. Ovary partially or entirely posttesticular. Vitelline follicles in lateral groups in forebody. Metratermcomplex well developed. Excretory vesicle saccate. Intestinal parasites of marine fishes. Type and only species:

Received for publication 4 March 1977.

* Gulf Coast Research Laboratory, Ocean Springs, Mississippi 39564.

$\dagger$ Harold W. Manter Laboratory, University of Nebraska State Museum, Lincoln, Nebraska 68588 .

\section{Panopula cavernossa sp. $n$. \\ (Fig. 1)}

Description (based on four mounted specimens): Body somewhat rounded posteriorly, 1,566 to 2,070 long by 719 to 945 in maximal width at or near midlevel; spines narrow, densest and reaching 13 $\mu \mathrm{m}$ long anteriorly, shorter and less numerous over remainder of body. Cellular masses within parenchyma. Oral sucker subterminal, 235 to 273 long by 258 to 302 wide, with mouth anteroventral. Acetabulum prominent, eversible, 534 to 609 long by 500 to 586 wide; posterior lip with medial tegumental pit. Sucker-width ratio $1: 2.1$ to 2.2 in three specimens with nonextruded suckers. Forebody normally 47 to $49 \%$ of body length. Pharynx 107 to 131 long by 119 to 142 wide, with thickened muscular border along anterior and peripheral borders allowing formation of lobular structures, usually contiguous with oral sucker. Prepharynx thick walled, shorter than $1 / 2$ length of pharynx. Esophagus thick walled, rugose internally in posterior portion, occasionally bent, 1.5 to over 2 times length of pharynx. Intestinal bifurcation approximately midway between suckers; ceca approximately as wide as pharynx, ending blindly usually lateral to anterior $1 / 4$ of acetabulum.

Testes near or partially overlapping middle or anterior portion of acetabulum, anterior portion ventral to cecal tips, symmetrical or subsymmetrical, smooth, longer than wide; right testis 252 to 284 by 122 to 189 ; left testis 232 to 267 by 142 to 165 . Genital pore marginal, near level of intestinal bifurcation. Cirrus sac 522 to 563 long by 167 to 197 in maximal width, nearly straight, thick walled, extending diagonally from near anterior border of acetabulum to near left margin of body; containing numerous relatively small prostatic cells, narrow coiled seminal vesicle, extremely muscular cirrus and pars prostatica together comprising 70 to $75 \%$ of sac length; cirrus as long or longer than prostatic duct; pars prostatica usually wider than cirrus, lined with elongated, granule-filled, epithelial cells with basal nuclei. Sperm and granular material observed emitted together.

Ovary dextral, subtriangular, 155 to 183 long by 

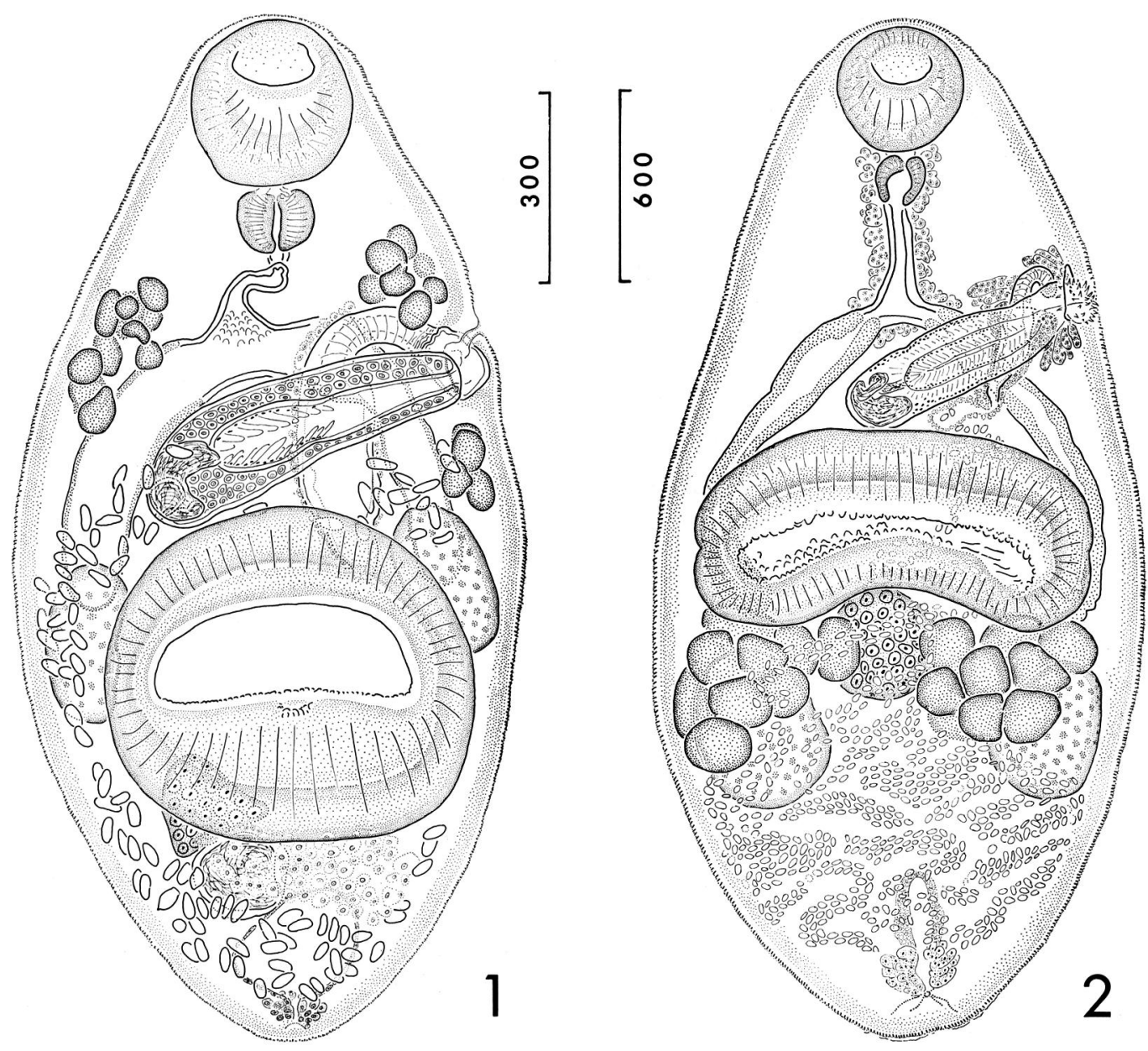

Figures 1, 2. New zoogonid trematodes from deep-sea fishes in the Gulf of Panama. 1. Panopula cavernossa, holotype, ventral view. Omitted are part of Mehlis' gland ventral to seminal receptacle and ovary, numerous eggs, and single cells and masses of glandular cells both approximating the size of eggs within the parenchyma; the glandular bodies occupy primarily the forebody and periphery of hindbody. 2. Neosteganoderma gillissi, holotype, ventral view. Omitted are numerous eggs and masses of glandular cells approximating the size of eggs; the masses occupy primarily the forebody and margins of hindbody. Scale values are micrometers.

174 to 241 wide, normally dorsal to posterior border of acetabulum. Seminal receptacle contiguous with posterior border of ovary, spheroid, about same size as ovary except in one when enlarged to 420 in diameter. Mehlis' gland complex conspicuous, ventromedian to seminal receptacle. Laurer's canal present. Uterus filling most available space in hindbody plus that space dorsolateral to acetabulum, looping some immediately anterior to acetabulum. Metraterm thick walled, separated by sphincter from spacious muscular organ (probably same as terminal organ of monorchiids, but, herein, it and muscular distal uterus referred to as metraterm-complex); organ about as long as cirrus sac, surrounded by inconspicuous gland-like cells, with wide posterior portion 67 to 142 across at widest point and narrow distal portion, extending anteriorly dorsal to cirrus sac and recurving posterolaterally to join genital atrium. Atrium 116 to 122 long by 84 to 96 wide, separated from marginal pore by sphincter 20 to 80 long. Eggs 32 to 46 long by 17 to 27 wide, each with inconspicuous operculum and small mucron on anopercular end. Vitelline follicles 32 to 104 long, 9 to 15 in one group on right side between pharyngeal and acetabular levels, 12 to 17 on left side in two groups separated by genital atrium, occasionally with few follicles dorsal and ventral to atrium.

Excretory vesicle subspherical, reaching to near female-complex; pore subterminal, dorsal, with 
associated sphincter surrounded by numerous cells; primary collecting-vessels single pair, each duct extending anteriorly lateral to acetabulum.

Type host: Enchelybrotula (?) paucidens Smith and Radcliffe (Brotulidae) deposited as UMML No. 32883. The identification is questioned because $E$. paucidens is known only from the holotype from the Gulf of Tomini, Celebes (Radcliffe, 1913).

Site: Midintestine.

Locality: Between $6^{\circ} 42^{\prime} \mathrm{N}, 78^{\circ} 56^{\prime} \mathrm{W}$ and $6^{\circ} 44^{\prime} \mathrm{N}$, $78^{\circ} 54.5^{\prime} \mathrm{W}$ at approximately 3,173 to 3,208 meters. Holotype: USNM Helm. Coll. No. 74492; paratype: U. Nebraska State Museum, Manter Lab. No. 20840.

Etymology: The generic name Panopula is the diminutive of the Latin mythological sea-nymph Panope. It should be treated as feminine in gender. The Latin specific name cavernossa refers to the tegumental pit overlying the acetabulum.

\section{DISCUSSION}

Having a postequatorial acetabulum, testes near the anterior of the acetabulum, and a posttesticular ovary, Panopula cavernossa can be differentiated from all other species of the Steganodermatinae. Still, because of its relationships with members of Deretrema Linton 1910, Pseudochetosoma Dollfus 1951, and Brachyenteron Manter 1934, all of which have preacetabular vitellaria, we place it in that subfamily.

Most species of Deretrema form a welldelineated group of somewhat elongated worms inhabiting the gall bladder of marine fishes from the North Pacific Ocean (see Yamaguti, 1971). These worms have a relatively small cirrus sac compared to $P$. cavernossa and have long ceca ending at or past the level of the testes. The presence or absence of tegumental spines and relative size of the acetabulum hold no generic significance.

A few species of Deretrema and Pseudochetosoma do not belong in their designated genera. Two species of Pseudochetosoma, P. salmonicola Dollfus 1951 and P. leucisci Ergens 1963, can be aligned on the basis of having ceca terminating anterior to the testes and infecting freshwater fishes in North Africa and Europe. The third species, P. spinosa (Polyanski 1955) Yamaguti 1971, does not fit in that convenient group. In fact, that species from a wolffish in the Barents Sea apparently differs from D. pycnorganum (Rees 1953) Yamaguti 1958 off nearby Iceland, also from a wolffish, on the basis of not having a well-developed metraterm-complex. Perhaps a reexamination of $P$. spinosa would reveal the two as synonyms. In any event, neither fusiform-shaped species belongs in Deretrema since each possesses a relatively large cirrus sac and short ceca terminating anterior to the acetabulum; we place them into Brachyenteron as $B$. pycnorganum (Rees 1953) comb. n. and $B$. spinosum (Polyanski 1955) comb. n. Another atypical Deretrema, one most similar to $P$. cavernossa, is D. minutum Manter 1954 from Galaxias attenuatus (Jenyns) in New Zealand which has short ceca, a large cirrus sac, and an intertesticular ovary. Additionally, it inhabits the intestine rather than the gall bladder. Other species reported from the intestine, $D$. parapriacanthi Yamaguti 1959, D. acutum Pritchard 1963, and D. fusillus Linton 1910, may have moved there after the death of the host or when otherwise stressed. The latter, the type-species from Florida, presents a special problem because it is reported to lack a seminal receptacle and possess a Y-shaped excretory vesicle. Those features would demand removal of the type from Zoogonidae Odhner 1911, but they may have been misinterpreted (Manter, 1947). Consequently, clarification of the entire subfamily necessitates collection of additional species and specimens and reexamination of types.

The primary diagnostic character of Steganodermatinae, in our opinion, is the presence of follicular vitellaria. In fact, Dollfus (1952) raised the subfamily to familiar rank to accept species with pretesticular lateral follicles, leaving Zoogonidae for those with compact posttesticular vitellaria. Possessing less affinity with $P$. cavernossa, but still considered by us as Steganodermatinae to be placed there with others listed by Yamaguti (1971) are Brevicreadium congeri Manter 1954 and Hudsonia agassizi Campbell 1975. Yamaguti, placing more emphasis on the prominent acetabular lips than on vitellaria, considered $B$. congeri in the Diphtherostominae Stossich 1904. Campbell (1975) erected a separate subfamily for $H$. agassizi because the worm had a combination of pretesticular uterus, acetabulum with glandular papillae, elongated and muscular genital atrium surrounded by a glandular mass, and deep-sea host. In view of our new species, 
we believe that the variations in terminal genitalia and the location of the testes which ultimately determine the relative uterine position are only of generic importance. Modifications of the acetabulum probably relate more to needs for attachment to a worm's host or mate than to its phylogenetic position. In fact, structures within the acetabulum similar, but different, to those described by Campbell (1975) were reported from Plectognathotrema tsushimaense Kamegai 1970 and not considered by Kamegai (1970) to be of generic significance. Kamegai placed his trematode, similar in several other respects to the one described by Campbell, into the poorly understood cephaloporids, some members of which had been considered aberrant zoogonids as early as 1937 by Price.

\section{Neosteganoderma gillissi sp. n.} (Fig. 2)

Description (based on 1 specimen): Body spined, fusiform, more rounded posteriorly than anteriorly, 3,240 long by 1,546 wide at acetabular level, yellowish-orange in life; spines covering entire body, somewhat more dense anteriorly, up to 22 long by 6 wide at base. Cellular masses within parenchyma. Oral sucker subterminal, 391 long by 405 wide, mouth anteroventral. Acetabulum 1,241 wide by 505 long along midline and 563 at longest point, possessing rugose aspinose tegumental lining and slight indentation at lateral margins. Suckerwidth ratio $1: 3.1$. Forebody $40 \%$ of body length. Pharynx 157 long by 165 wide. Prepharynx muscular, shorter than $1 / 2$ length of pharynx. Esophagus muscular, 304 long, surrounded by gland cells; gland cells also surrounding pharynx and cecal bifurcation. Ceca bifurcating about midway between suckers, terminating at posterior border of sucker; epithelial lining thick, absent anteriorly at bifurcation.

Testes postacetabular, symmetrical, subspherical; right testis 534 long by 413 wide; left testis 448 by 345 . Posttesticular space $23 \%$ of body length. Genital pore sinistral, submarginal near level of intestinal bifurcation. Cirrus sac nearly straight, 715 long by 226 wide, extending diagonally from anterior margin of acetabulum to genital pore; containing coiled seminal vesicle, 488 long pars prostatica lined with elongated cells with basal nuclei, elongated prostatic cells surrounding pars prostatica having nuclei situated near wall of cirrus sac, and muscular cirrus with thorn-shaped spines up to 29 long and 15 wide at base.

Ovary medial, subspherical, 362 long by 367 wide. Mehlis' gland predominantly between ovary and left testis; seminal receptacle indistinct; Laurer's canal present. Vitelline follicles between 155 and 235 long, ventral, underlying ovary and testes, with 11 in left group and 9 in right. Uterine loops filling available space in hindbody and some space dorsal to acetabulum. Metraterm-complex with true metraterm measuring less than that of more distal portion; distal portion shorter than cirrus sac and 86 at widest point, dorsal to cirrus sac and ventral to left cecum, extending anterior to cirrus sac before recurving to join genital atrium, surrounded by thin layer of small glandular cells one to three cells thick and becoming clumped and encapsulated in elongated groups adjacent to genital atrium. Eggs thick shelled, with additional slight thickening at anopercular end, operculated, 28 to 36 long by 16 to 24 wide.

Excretory vesicle saccular, extending to the anterior $1 / 4$ of posttesticular area, surrounded by numerous small cells; pore subterminal, dorsal.

Type host: Synaphobranchus bathybius Gunther (Synaphobranchidae), UMML No. 31350.

Site: Anterior portion of intestine.

Locality: Between $6^{\circ} 42^{\prime} \mathrm{N}, 78^{\circ} 56^{\prime} \mathrm{W}$ and $6^{\circ} 44^{\prime} \mathrm{N}$, $78^{\circ} 54.5^{\prime} \mathrm{W}$ at approximately 3,173 to 3,208 meters.

Holotype: USNM Helm. Coll. No. 74493.

Etymology: The specific name gillissi refers to the R/V JAMES M. GILLISS aboard which the host was trawled.

\section{DISCUSSION}

Yamaguti (1971) considered Neosteganoderma Byrd 1964 a synonym of Proctophantastes Odhner 1911. Bray (1973), however, resurrected the genus, assuming Yamaguti based his definition of Proctophantastes on one of his own species rather than the type-species, $P$. abyssorum Odhner 1911. We agree with Manter (1947) and Bray (1973) in considering Proctophantastes a synonym of Steganoderma Stafford 1904 and with Bray in utilizing the large glandular mass about the genital atrium as the most reliable character separating $\mathrm{NeO}$ steganoderma from Steganoderma. In this regard, we consider Neosteganoderma to include $N$. glandulosum Byrd 1964, N. polymixiae (Yamaguti 1970) Bray 1973, N. infundibulum (Kamegai 1973) comb. n., and N. gillissi.

With the exception of $N$. glandulosum, species are based on one or two specimens, and, consequently, intraspecific morphologic variation is uncertain. Byrd (1964) and Bray (1973) both considered the type to be extremely variable. Therefore, without utilizing measurements and ratios, we distinguish $N$. gillissi from the other species by its possession of conspicuous glandular cells surrounding the esophagus and pharynx, glandular cells about the genital atrium being arranged in several 
sacs, and the thick muscular lining of the esophagus extending into the ceca. A straight rather than arcuate cirrus sac with the distal portion of the metraterm-complex entering the genital atrium anteriorly rather than laterally or posteriorly may also prove to remain good distinguishing characters. The most dissimilar species in the genus, $N$. infundibulum, has a funnel-shaped oral sucker, intestinal-type epithelium extending into the esophagus, and ceca extending well posterior to the acetabulum (Kamegai, 1973). The extension of the intestinal epithelial lining in the other two species, suggested as possible synonyms of each other by Bray (1973), reaches farther anteriorly than in $N$. gillissi.

\section{ACKNOWLEDGMENTS}

We thank Drs. Gilbert Voss and Jon Staiger of the University of Miami for permitting the senior author to participate in the cruise. Dr. Catherine Robins, also from Miami, and Dr. Daniel Cohen of the U.S. National Museum identified the eel and brotulid, respectively. Ronnie G. Palmer and Ann St. Andrie provided technical assistance. The paper constitutes "Biological Results of the University of Miami Deep-Sea Expeditions. 124," and we acknowledge the National Geographic Society and block funding for ship support by the National Science Foundation.

\section{LITERATURE CITED}

Bray, R. A. 1973. Some digenetic trematodes in fishes from the Bay of Biscay and nearby waters. Bull Br Mus Nat Hist, Zool 26: 151183.

BYrD, M. A. 1964. Neosteganoderma glandulosa gen. n., sp. n. (Trematoda: Steganodermatidae) from an Atlantic fish. Proc Helminthol Soc Wash 31: 105-108.

CAMpbell, R. A. 1975. Hudsonia agassizi gen. et sp. n. (Zoogonidae: Hudsoniinae subf. n.) from a deep-sea fish in the western North Atlantic. J Parasitol 61: 409-412.

Dollfus, R. PH. 1952. Miscellanea helminthologica maroccana. IV. Affinités naturelles de Pseudochetosoma salmonicola R. Ph. Dollfus 1951 (Famille Steganodermatidae nov.).emendation de la Superfamille Haploporoidea W. Nicoll 1935. Arch Inst Pasteur Maroc 4: 369-386.

KAMEgAI, S. 1970. Plectognathotrema (Alloplectognathotrema) tsushimaense n. subg., $\mathrm{n}$. sp. (Trematoda: Cephaloporidae, Plectognathotrematinae n. subfam.), from intestine of marine fish, Navodon modestus. Res Bull Meguro Parasitol Mus 3 : 1-7.

1973. Zoogonid trematodes from marine fishes near the Tsushima Islands in the Sea of Japan. Res Bull Meguro Parasitol Mus 7: 19-23.

Manter, H. W. 1947. The digenetic trematodes of marine fishes of Tortugas, Florida. Am Midl Nat 38: $257-416$.

Price, E. W. 1937. Three new genera and species of trematodes from cold-blooded vertebrates. Rabot Gel'mint (Skrjabin), p. 483490.

RADCLIFFE, L. 1913. Descriptions of seven new genera and thirty-one new species of fishes of the families Brotulidae and Carapidae from the Philippine Islands and the Dutch East Indies. Proc U S Nat Mus 44: 135-176.

YAMAGUTI, S. 1971. Synopsis of the Digenetic Trematodes of Vertebrates. Keigaku Publ. Co., Tokyo, 1074 p., 349 pls. 